\title{
Fteknokultura
}

\#Eglash, R. (2016). Of Marx and Makers: an Historical Perspective on Generative Justice, Revista Teknokultura Vol. 13(1), 245-269.

Recibido: $13-03-2016$

Aceptado: 28-04-2016
Open peer review

http://revistas.ucm.es/index.php/TEKN/pages/view/opr-52096

\section{Of Marx and Makers: \\ an Historical Perspective on Generative Justice}

\author{
De Marx y Makers: \\ una perspectiva histórica sobre la justicia generativa \\ Ron Eglash \\ Rensselaer Polytechnic Institute (RPI) \\ eglasherpi.edu
}

\begin{abstract}
In Marxist frameworks "distributive justice" depends on extracting value through a centralized state. Many new social movements-peer to peer economy, maker activism, community agriculture, queer ecology, etc.-take the opposite approach, keeping value in its unalienated form and allowing it to freely circulate from the bottom up. Unlike Marxism, there is no general theory for bottom-up, unalienated value circulation. This paper examines the concept of "generative justice" through an historical contrast between Marx's writings and the indigenous cultures that he drew upon. Marx erroneously concluded that while indigenous cultures had unalienated forms of production, only centralized value extraction
\end{abstract}


could allow the productivity needed for a high quality of life. To the contrary, indigenous cultures now provide a robust model for the "gift economy" that underpins open source technological production, agroecology, and restorative approaches to civil rights. Expanding Marx's concept of unalienated labor value to include unalienated ecological (nonhuman) value, as well as the domain of freedom in speech, sexual orientation, spirituality and other forms of "expressive" value, we arrive at an historically informed perspective for generative justice.

\section{KEYWORDS}

Generative justice; peer-to-peer; maker; DIY; indigenous; queer ecology.

\section{Resumen}

En términos marxistas, la "justicia distributiva" depende de la extracción de valor a través de un estado centralizado. Muchos de los nuevos movimientos sociales centrados en la economía peer to peer, el activismo fabricante, la agricultura comunitaria, ecología queer, etc., toman el camino contrario: mantener el valor en su forma alienada permitiendo que circule libremente desde abajo hacia arriba. A diferencia del marxismo, no existe una teoría general de abajo hacia arriba sobre la circulación del valor no alienado. Este artículo examina el concepto de "justicia generativa" a través de un contraste histórico entre los escritos de Marx y las culturas indígenas en que se basó. Marx llegó a la conclusión errónea de que, mientras que las culturas indígenas tenían formas enajenadas de producción, sólo el valor de la extracción centralizada podría permitir la productividad necesaria para una alta calidad de vida. Sin embargo, las culturas indígenas ahora proporcionan un modelo sólido para la "economía del don" que sustenta la producción tecnológica de código abierto, la agroecología y las aproximaciones de restitución de los derechos civiles. Ampliando el concepto del valor del trabajo no alienado de Marx para incluir el valor no alienado ecológico (no humano), así como el dominio de la libertad de expresión, la orientación sexual, la espiritualidad y otras formas de valor "expresiva", llegamos a una definición de la justicia generativa.

\section{Palabras Clave}

Justicia generativa; Peer-to-Peer; fabricante; DIY; indígena; ecología queer. 


\section{Contents}

1. Introduction

2. The creation of value: Smith versus Marx

3. Unalienated value and self-generation

4. The failure of Marx's vision

5. The present and future of generative justice

6. Acknowledgement

7. References

\section{Contenidos}

1. Introducción

2. La creación del valor: Smith versus Marx

3. El desacierto de la perspectiva de Marx

4. El presente y el futuro de la justica generativa

5. Agradecimientos

6. Referencias 



\section{Introduction}

The promise of distributive justice--Marx's vision of capitalism's technological productivity re-routed through a top-down, state-run economy--was greatly tarnished once the world learned of the human rights nightmares under communist states such as the USSR, Cambodia, and China. Yet the current poverty, pollution, militarism, and other deprivations under free market systems make the search for alternative forms a matter of survival. A new set of practices has recently emerged which attempt to provide social justice and sustainability through bottom-up organizational forms. The "gift economy" of open source software; open access resources such as Wikipedia; the rise of community agriculture; the experiments with local currencies; and the explosion of DIY movements--ranging from "craftivism" textiles to home-brewed radiation detectors to feminist makerspaces--all point to the need for a new theoretical framework that can stand on its own. We refer to this alternative as "generative justice". This essay will provide some historical background to the contrast between theories of distributive justice and generative justice, and briefly provide some examples to illustrate how generative analysis can help us think about futures which are both just and sustainable for humans and nonhumans alike.

Examples such as those above already have their own separate frameworks: open source is explained in a "commons-based peer production" theory (Benkler, 2013); organic agriculture is explained by agroecology theory (Altieri, 2004); the importance of women's makerspaces by feminist theory (Fox et al., 2015), and so on. Generative justice can offer a shared framework based on the bottom-up circulation of unalienated value. By extending the concept of unalienated labor value as originally proposed by Marx, we can also accommodate non-human "ecological" value (biodiversity, organic soils, etc.), as well as "expressive" value (freedom in speech, sexuality, spirituality, arts, etc.). All three typeslabor value, ecological value, and expressive value--are essential. Elsewhere (Eglash and Garvey, 2014; Eglash, 2016) we have discussed how to apply generative justice to realworld case studies, but here I would like to begin with an historical question: if the concept of unalienated value was so fundamental to Marx, why did he insist on top-down centralization of extracted value, rather than bottom-up circulation in its unalienated forms? Once we have answered that question, we can proceed to examine some of the contemporary forms of generative justice, and consider its potential for encompassing an entire technosocial landscape. 


\section{The creation of value: Smith versus Marx}

To understand what is meant by "bottom-up value generation" it is helpful to start with the contrast between Adam Smith and Karl Marx. Both maintained that the basis for any economy is the "labor value" of its commodities. But they defined this in different ways. For Smith, the value of a commodity was in how much labor one could exchange for it: that is to say, its price in a market that sells both labor and things. Figure 1 shows how Adam Smith's view of value transfer in capitalism might have been diagrammed as a flow chart.

Figure 1: capitalism as SEen by Adam Smith

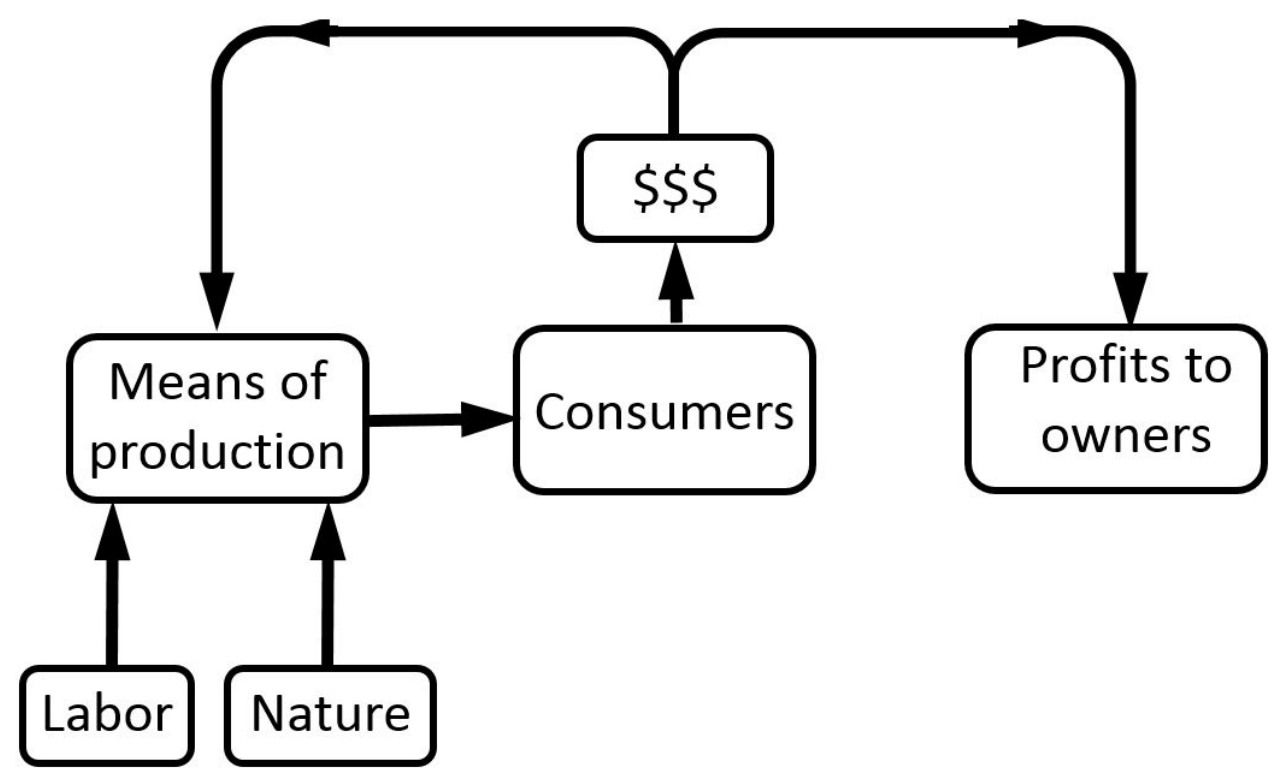

Source: The author.

Of course a real representation would be massively complicated; this is just a schematic to visualize which connections Smith emphasized the most. The crucial feature for Smith was its positive feedback loop in the upper left: in his eyes a "self-generating" source for increasing the wealth of nations. In Smith's view there was no limit to the inputs for production, as innovation would constantly improve extraction from nature (e.g. agriculture) and extraction from labor (e.g. specialization resulting in low-wage, unskilled workers). Thus, although his scheme did allow returns such as fertilizer or wages, we have 
drawn no arrows for it; as he specifies that these values should be kept at the absolute minimum required. Indeed he suggested that the correct, market-determined wages to workers would be barely at subsistence level in zero population growth conditions. Only if sales justified higher wages would the population increase: thus "The most decisive mark of the prosperity of any country is the increase of the number of its inhabitants" (Smith, 1776, p. 29). In other words, the only way to keep an economy growing, for Smith is constant population expansion (Lange 2012).

Unlike the "physiocrats"-economists such as Quesnay who believed that only Nature generated economic value--Smith insisted that manufacturers and merchants would naturally tend to reinvest their profits into more factories and stores (Eltis, 1988). History vindicated Smith in the short run: by the middle of the 19th century, Britain's industrial and commercial profits created about 30\% of her GDP; agriculture only 13\% (Mathews et al., 1982). Yet in the long run, we now know that Smith's cycle of expanding capitalism created unprecedented levels of environmental, economic, and social damage. Global warming, toxic waste, overpopulation, ecological degradation, and resource depletion now threatens our earthly survival. Income inequality in Europe and the US diminished briefly during the middle of the 20th century (due to the 1930s depression and the 1940s effects of WWII), but by 1970 it began to skyrocket upwards: the top $1 \%$ of the world's wealthy now own $50 \%$ of the wealth (Fuentes-Nieva \& Galasso, 2014). In the Middle East and Africa, inequality has often created cycles of revolution against entrenched elites, followed by brutal military or theocratic regimes. Even in the relatively prosperous US, poverty levels in 2012 were at $16 \%$. Where did Smith's analysis go wrong?

While Smith thought of value in terms of what you are willing to exchange for a commodity, Marx thought of value as what it takes to generate a commodity. This missing part of the flow chart is central to understanding the failure of Smith's model: without accounting for the truly self-generating sources of value, there is no way to keep its human and non-human inhabitants flourishing. Yet Marx's application of this insight for a model of the future communist state was also tragically flawed. 


\section{Unalienated value and self-generation}

In contrast to Smith's claim that industrial capital offered a self-generating source of value, Marx focused on labor and nature as the only components that are truly self-generating ${ }^{1}$. Some of his best examples are the indigenous societies described in his Ethnological Notebooks. Drawing on Lewis Morgan's work with the Iroquois and other early anthropologists, Marx noted that in these indigenous societies the labor that goes into growing a bushel of corn or crafting a knife is visible rather than hidden, and relations of reciprocity, communal sharing, and gift-giving, rather than cold blooded calculation, allowed that labor value to circulate in an unalienated form (Graeber, 2012). While not all indigenous societies were egalitarian, examples such as the Iroquois, who had a rich structure for democratic decisionmaking--establishing women's voting rights 500 years before any European nation did sowere ample evidence that without the wealth inequality created by capitalism, deep political equality would be possible.

From the viewpoint of Adam Smith, the economic value of a commodity is the revenue you get by selling it, so it is only common sense that the owner of a factory owns all its profits. For Marx the owner of the factory is extracting value from the labor that generated it, and unethically hoarding that value in the form of profits. Workers are complacent in part because the monetary system of banks and bills makes the hording invisible: I don't see my boss putting a thousand ears of corn in his wallet, while only 10 ears go into mine. But they are also complacent because replacing the experience of artisanal production-pride in crafting, contributing and communing with tools, users and resources-with the mind numbing alienation of mass production drastically changes one's perspective: consumption becomes the only form of identity, and social, cultural and political structures begin to reflect the consumer mentality.

1 Of course Marx knew that labor does not magically produce something from nothing; indeed he was strongly influenced by the new science of thermodynamics (Wendling 2009). In his Critique of the Gotha Program he states "Labor is not the source of all wealth. Nature is just as much the source of use values." While Marx was familiar with the findings of Liebig, Helmholtz and others that all energy ultimately derives from the sun, his focus was the role of human agency in transforming nature. Below we will amend that to include non-human agency as well. 
In addition to unalienated labor value, Marx eventually noted the importance of unalienated ecological value. In earlier writing (letter of January 7, 1851) he scoffed at the need for environmental protection because of "the progress of science and industry." But by the 1860s, inspired by the new soil chemistry studies of Justus von Liebig (Foster and Magdoff, 2011), he critiqued capitalist agriculture for the way it "disturbs the metabolic interaction between man and the earth, i.e. it prevents the return to the soil of its constituent elements consumed by man in the form of food and clothing...All progress in capitalist agriculture is a progress in the art, not only of robbing the worker, but of robbing the soil..." (Marx 1976, pp. 637-638).

Although not emphasized as much as labor and nature, Marx also mapped out a third form which I will refer to as "expressive" value. In the Grundrisse, he predicted that technological improvements under communism would create so much wealth that workers would have abundant free time in the form of unalienated intellectual pursuits, arts, recreation, and other creative and emotional expressions. As a practicing journalist for most of his career (publishing 362 articles in The New York Tribune alone), Marx also highlighted expressive value in media: "The free press is the ubiquitous vigilant eye of a people's soul, the embodiment of a people's faith in itself" (Marx, 1842).

Figure 2: Flow of value in Marx’s theory of Communism

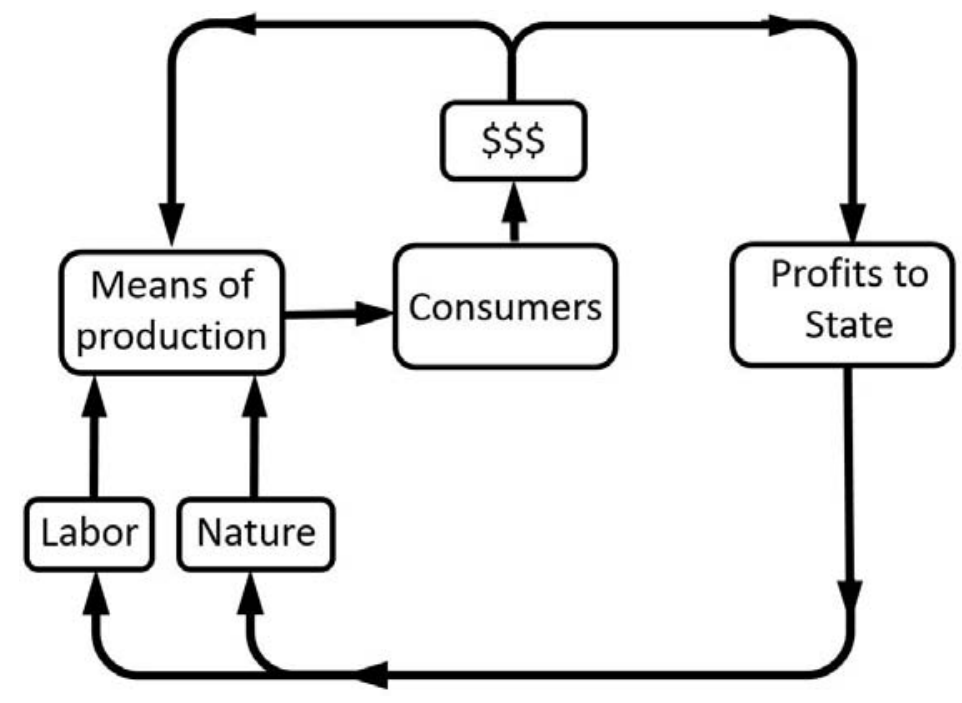

Source: The author. 


\section{The failure of Marx's vision}

With these three pillars of unalienated labor, ecological, and expressive value, one can understand the optimism of the 1917 revolution in what would become the USSR. It's hard to imagine a more horrifyingly failed vision. Rather than return people to the egalitarian relations of indigenous societies, the USSR was marked by widespread poverty, income inequality, environmental degradation, rampant militarism and a human rights record so bad that new terms like "Orwellian" had to be created for it. Davies (1998) for example notes that the death toll due to Stalin-era economic policies has been estimated at 10 million. Even with "cost savings" measures such as forced labor camps, about 30 million (one of every 8 citizens) were still living in poverty by the dissolution in 1990 (Slay, 2009). Where did Marxist analysis go wrong?

In all three domains Marx demonstrated the advantages of unalienated forms. But his model of communism could not accommodate the very phenomena he used to justify it. Figure 2 shows the flow of value under communism: as in the case of Adam Smith's capitalist system, it communism required that value must be extracted. In part that was required by centralization, which Marx saw as the only means to redistribute value. His 1848 Manifesto of the Communist Party calls for strict centralization of "all instruments of production" (factories, machines, agricultural estates, mines, etc.) as well as finances, communication, transportation, and even the workforce--an "industrial army"--in the hands of the state (1974, pp. 86-87). But equally important was Marx's conviction that the unalienated labor of traditional cultures was simply too inefficient. Providing barely enough for subsistence; it could not rise beyond "nature's paltriness" (Natur-bedurftigkeit). Capitalism was a necessary stage before communism because it could condense the labor value of past generations into increasingly efficient technologies.

It was this requirement of extraction, and its corollary of centralized redistribution, that created the ideology and methods at the heart of the USSR disasters. Labor value extraction turned out to be as alienating under communism as it was under capitalism. Nature's contribution to the generation of value was similarly betrayed: plants came out of farms, but organic waste was not brought back to the soil. Artificial phosphorus additives in the USSR became so high that following its dissolution in 1990, world phosphorus consumption dropped for a decade (MIT, 2011). 
The USSR failure to liberate expressive value was equally disastrous. In 1962, for example, premier Khrushchev denounced artists who dared to veer from the official policy of Socialist Realism as "homosexuals;" an illustration of how the values generated at the core of our being - our imagination, sexuality, curiosity, spirituality, and other expressions of our individual and collective humanity - was to be extracted and controlled like any other (Taubman, 2004, pp. 589-591). The Lysenko affair (Graham 1993), in which a false theory of environmentally acquired genetic characteristics became official state doctrine, suppressed authentic genetic science in striking parallel to the logic behind Khrushchev's suppression of arts and sexuality: the inherently creative, unpredictable aspects of bottomup value generation in nature --the monsters of mutation (Haraway, 1992)--are incompatible with authoritarian ideology. It is not, as Soviet propagandists claimed, a question of "balancing" creative expression with social justice; the flourishing of unalienated creative value is social justice. The relationship between human and non-human value generation is further illuminated by the ways that the lack of free speech rights in the USSR allowed horrific environmental and health disasters unencumbered by so much as a letter to the editor, let alone public protests (Feshbach and Friendly, 1993).

\section{The present and future of generative justice}

Thus in contrast to Marx's theory of distributive justice, we seek a theory of generative justice: one in which society is best served when value extraction is minimized, and when the communities who are generating value - not Adam Smith's capital or Marx's state - are in charge of its circulation. If we phrase this in the language of "rights"-which is not the only way to think about it--we can define generative justice as follows: The universal right to generate unalienated value and directly participate in its benefits; the rights of value generators to create their own conditions of production; and the rights of communities of value generation to nurture self-sustaining paths for its circulation.

Figure 3 shows a flowchart for generative justice in a case of traditional indigenous production, that of Adinkra cloth fabrication. The photos are from our fieldwork in Ghana, funded by the NSF 
Figure 3: Generative justice in the traditional AdinKra cloth system of Ghana

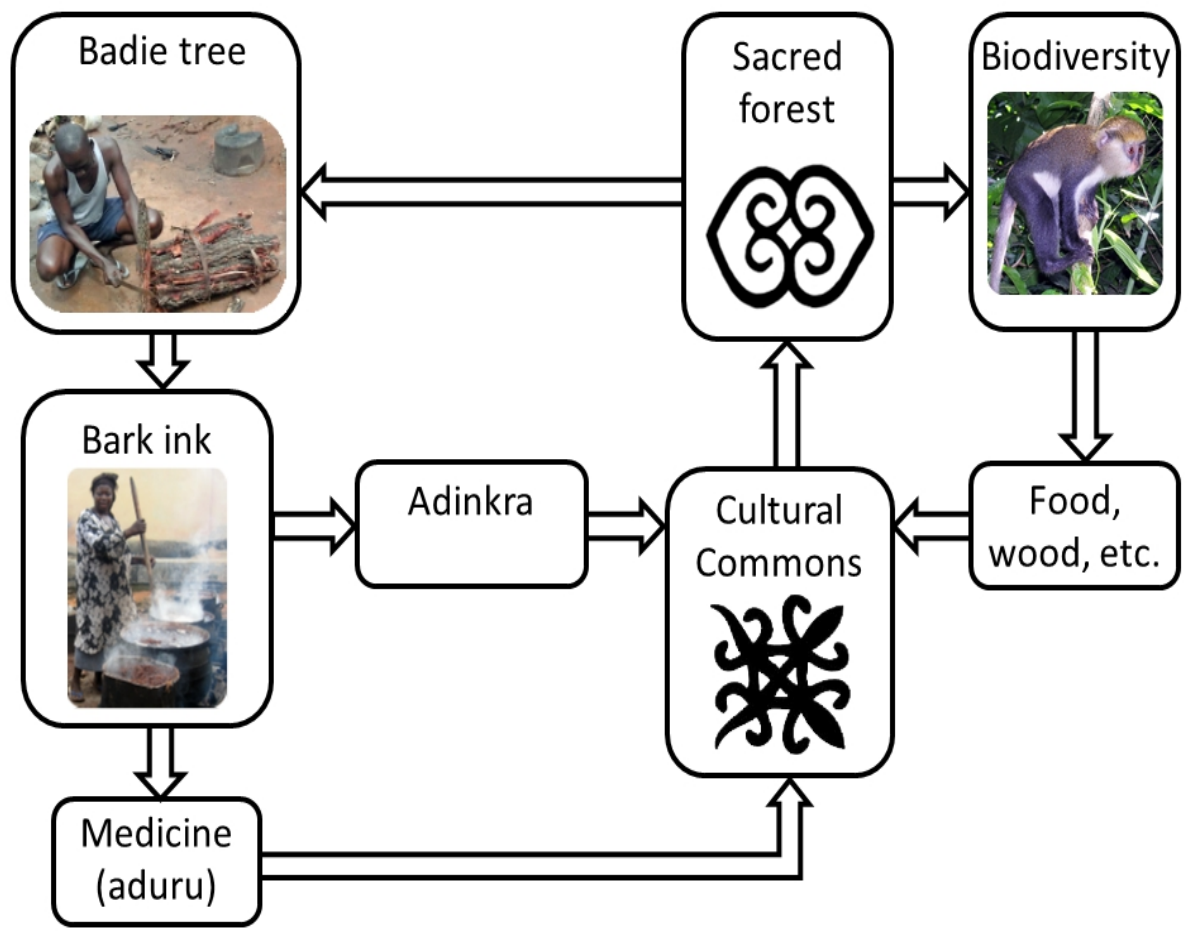

Source: The author.

GK-12 program. In figures 1 and 2 the flow of alienated value was graphed with single lines. But figure 3 shows the flow of unalienated value, so the lines are double to invoke the sense of a fuller, richer pathway. The process begins at the upper left with harvests of bark from the Badie tree (Bridelia ferruginea). The bark is selectively extracted so that the tree can recover. Soaking the pounded bark shavings produces a lightly colored water called 'adinkra aduru' (medicine) which has anti-inflammatory and analgesic properties (Olajide et al., 2000). After straining out the bark (which can then be used for growing mushrooms) the final boil produces a thick black ink for stamping the Adinkra symbols on cloth. Both the medicine and cloth contributed to a kind of cultural commons; a gift economy (based on principles from the traditional animist religion) which is still active today, albeit mixed with monetary exchanges, the tourist trade etc. The symbol in the commons, funtunfunefu, shows two crocodiles who share a single stomach. The symbol represents the fundamental gift eco- 
nomy principle: "by feeding you, I feed myself". A crucial function of the cultural commons is also sustaining forests against logging, farming and climate variance. Physical activities such as tree planting, dumping of organic waste and fire protection all contribute (Campbell, 2005). Our informants tell us that the forests which provide Badie tree bark are protected because of their utility, but other forests in the area are protected for spiritual reasons. The upper adinkra symbol, asase ye duru ("the earth has weight") uses paired logarithmic spirals to represent the importance of protecting the "life force" (Lachney et al., forthcoming). While these sacred forests are not extensive, they are wellsprings of biodiversity for the surrounding areas (Bossert et al., 2006; Sheridan and Nyamweru, 2007). For example some monkey populations (pictured above is a Cercopithecus mona in the sacred forest of Boabeng-Fiema) flourish by moving between them.

At first it might seem that the Adinkra production system, while admirable for its sustainability, is at best an artifact of the past. But the system took a remarkable turn in 1993 when a traditional animist priest, Nana Frimpong Abebrese, decided to organize cocoa farmers under similar principles: a collective in which the common pool of resources would benefit the whole. Kuapa Kokoo Ltd (the name means "good cocoa farmer") obtained a loan from Twin Trading, a UK fair trade company, and set up 22 villages with weighing scales, tarpaulins, gratings and other basics. Their mission is to empower low-income farmers, increase women's participation, and to develop environmentally friendly cultivation. In 1998, with the help of Twin and other NGOs, Kuapa Kokoo launched UK-based chocolate company Divine, with the funtunfunefu and asase symbols proudly displayed on the front wrapper (figure 4). Today Kuapa Kokoo has 65,000 members organized in about 1400 villages. Profits from their $45 \%$ ownership in Divine chocolate are reinvested in village projects for water, health, and education, as well as preventing child labor and adapting to climate change. 
Figure 4: Divine Chocolate

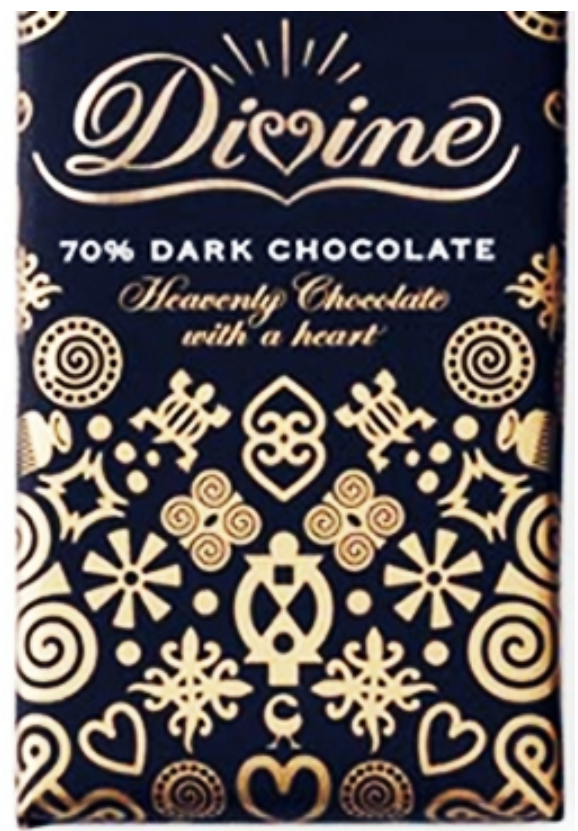

Source: The author.

When it comes to low-income African farmers becoming owners of a multimillion dollar chocolate empire, it's hard to argue against generative justice. But most cases are more messy and incomplete. In particular, unpaid online peer production - forms such as fan fiction and community cookbooks--are often derided as too trivial to matter (Keen, 2007). One clear counter-example is the Harry Potter Alliance, an online network of J.K. Rowling fiction enthusiasts who blend the usual fan activities with humanitarian causes (Jenkins, 2012). In 2010 they began to petition Warner Bros to use fair trade chocolate in the Potter World theme parks and other franchise venues After 4 years of activism they succeeded in forcing the change. Figure 5 diagrams the flows of value in this case. There are 3 cycles. At the upper left, the Warner Bros carries out the usual mass production techniques of any large corporation. At the lower right, the peer to peer production of the Harry Potter Alliance is more or less like any other fan club, albeit one with a strong humanitarian outlook. As detractors like Keen might point out, no matter how effective its outcomes, it's hard to see how unpaid labor can become self-sustaining; it will always be "parasitic" on the ordinary 
economy. But it is the presence of the upper right cycle that makes this an extraordinary system. This kind of hybrid production which participates in both generative and commercial cycles holds powerful potential for change.

\section{Figure 5: generative justice in the Harry Potter Alliance}

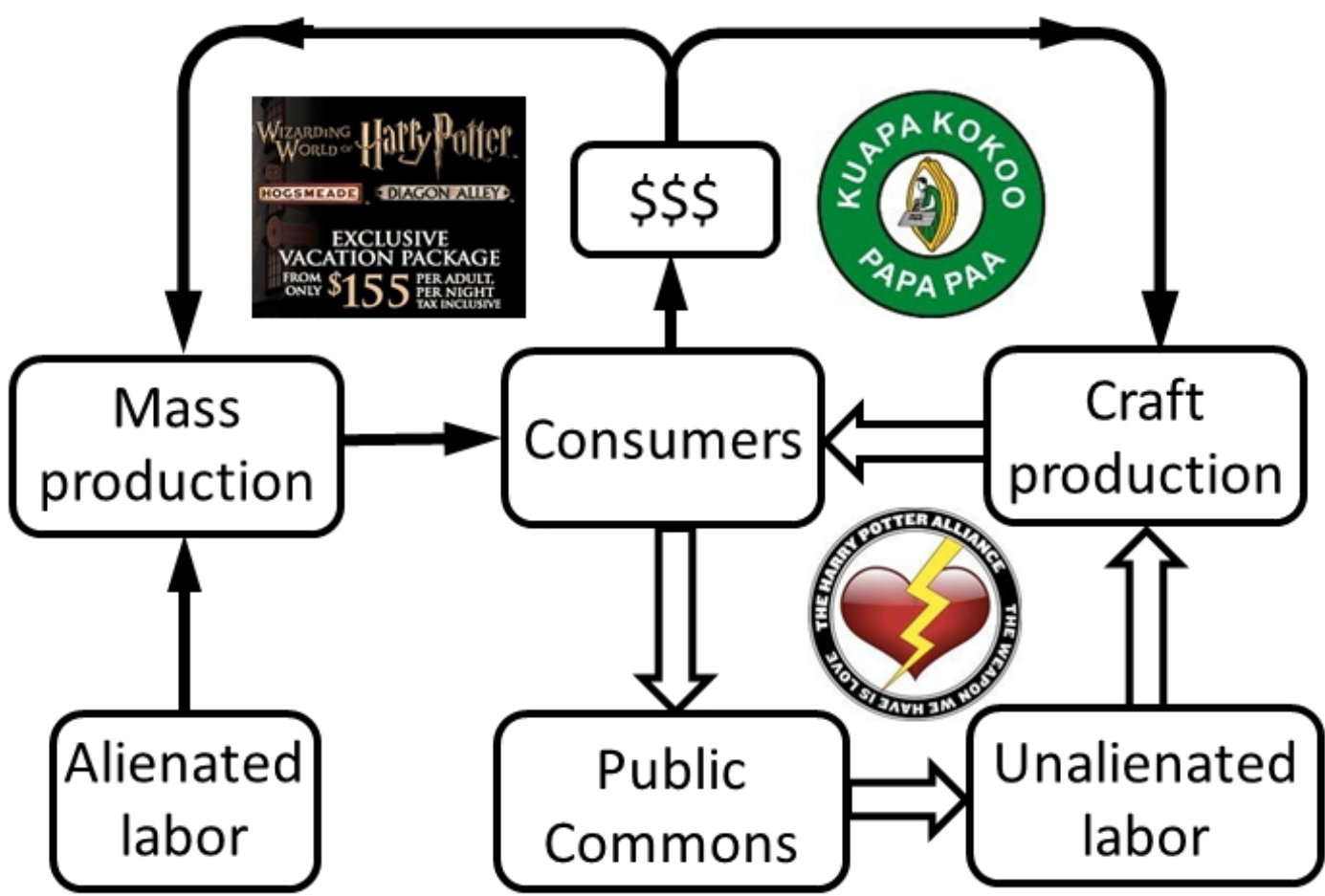

Upper left: alienated value in Warner Bros franchise

Lower right: peer production in the Harry Potter Alliance

Upper right: hybrid production in the Kuapa Kokoo cooperative

Source: The author.

Figure 6 shows the flow of value for the case of Arduino, an open-source, microprocessorequipped prototyping platform that has inspired a wide range of "maker" or "DIY" innovations created in artisanal, relatively unalienated mode of production. The parallels to the Kuapa Kokoo case is striking: 
Figure 6: Arduino PRODUCTION CyCles

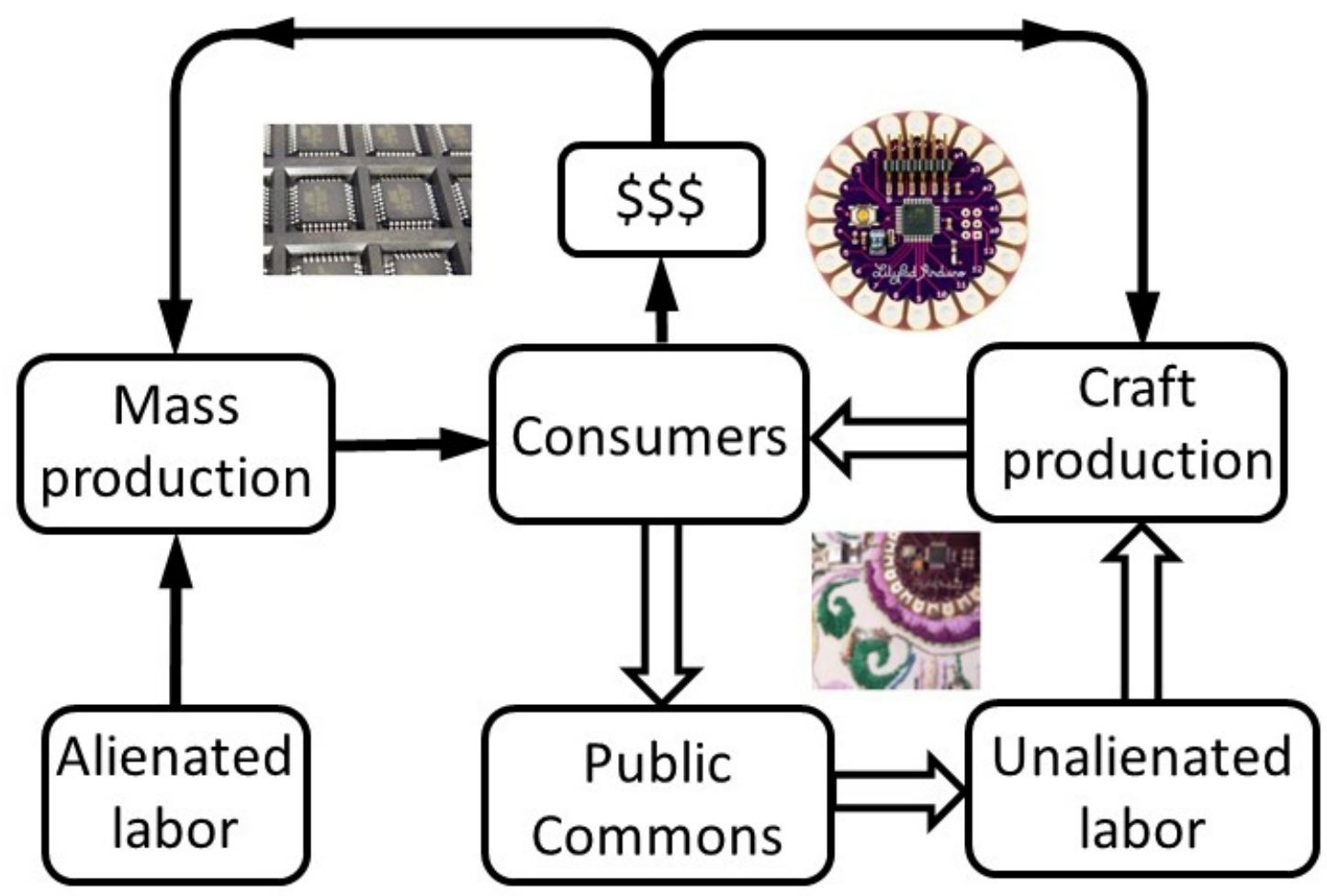

Upper left: alienated value in chip production

Lower right: peer production in the DIY community

Upper right: hybrid production in the LilyPad

Source: The author.

A) At the top left is the large scale factory production of components. The image here is a common Arduino microprocessor chip, under conditions which are typical of any mass production $^{2}$ : largely monotonous work for low wages; what Marx defined as an exploitative cycle (Sandoval, 2013). For that reason the flowchart arrows have the single lines of alienated value. Any mass produced item in the Arduino ecosystem, from sewing needles to solder, would be part of this extractive cycle.

2 In addition to low wages and monotony there are health hazards--for example, Blanding and White (2015) report that recent cost-cutting measures have put over $1 / 4$ of the Chinese labor force at risk of occupational pois oning--as well as problems such as conflict zones exacerbated by mining for rare earth minerals. 
B) At the lower right are largely handcrafted artistic and activist projects ranging from electronic textiles to sensors for environmentalists to the MakerNurse collection of low-cost medical devices. Because these are open source--allowing anyone the right to distribute, modify and make use of the software, hardware designs and other forms of intellectual property ${ }^{3}$--they are freely distributed in a "commons-based peer production" (Benkler, 2013) or, with analogy to indigenous traditions, a gift economy (Zeitlyn, 2003). For that reason the gifting cycle B arrows have the double lines of unalienated value flow. As noted many mass-produced materials are employed in these creations, and their alienated labor is represented in the extractive cycle.

C) At the upper right is the circular LilyPad Arduino created in the US by SparkFun. The companies that are typical of this cycle tend to combine artisanal, relatively unalienated labor styles and open source distribution with for-profit financial sustainability. For this reason hybrid cycle $\mathrm{C}$ arrows show alienated value flows where it is coupled with the corporate world of the extractive cycle, and unalienated value flows coupled with the gifting of cycle B.

Scholars from a traditional Marxist position focus largely on cycle A, the extractive mass production part of the flow. From their view that is the only significant aspect of the system; the rest is just neoliberal window dressing (e.g. Chopra and Dexter, 2006). Initial work in the peer production literature tended to focus on gift cycle B, often stressing its significance in the context of political protests, the replacement of passive entertainment with user agency, and similar advantages (e.g. Shirky, 2011). However increasing focus has shifted to peer to peer economy, with an eye towards the hybridity of cycle C. This includes "hybrid economy" (Lessig, 2009); "polycentric governance" (Ostrom, 2010), "peer mutualism" (Benkler, 2013), "collaborative economy" (Kostakis and Bauwens 2014); "solidarity economy" (Kawano et al., 2010; Penn and Shear 2015), "community economy" (GibsonGraham, 2006; Miller, 2013), "sharing economy" (Hamari et al., 2015), "real utopias" (Wright, 2013), and so on.

In the next issue of this journal I will provide details for this particular case study of Arduino, outlining its relations to not only unalienated value in labor practices but also ecological value (Arduino's role in environmental activism) and expressive value (Arduino as both protest technology and social affordance in activism for feminist, queer, decolonial, and related movements). But here I want to conclude by looking briefly at three implications for any case of generative justice.

3 According to BlackDuck (a common resource for open source statistics), about $90 \%$ of the software with open source licenses in 2015 is "free software," meaning they allow both distribution and modification. There are other open sources licenses possible: for example some differentiate between for-profit and nonprofit rights. 
First, we should welcome critiques such as McRobbie (2002), Ross (2007), Irani (2015) and Ekiba and Nardi (2014) who rightly condemn the ways that the unpaid peer production of cycle $\mathrm{B}$ is absorbed with little return from uncaring corporations. But if we allow the neoliberalism critique to overwhelm every analysis, we will erase awareness of the crucial rise of hybrid cycle $\mathrm{C}$, which is, at least to some extent, both decreased in alienation and yet economically self-sustaining (e.g. Bennett et al., 2015). And while hybrid cycles may be slow to replace extractive cycles, there are pathways which can gradually move production networks in this direction. Local exchange systems, such as BerkShares in the Berkshire region of Massachusetts, USA have shown how organic farming, worker cooperatives and other types of less alienated human and ecological value production can be supported using community currencies, time banks and other forms (Kim, 2015; Place, 2015); and their potential has increased with the introduction of open digital technologies for value exchange (Bellotti et al., 2013). These are all means to increase the systems "recursive depth" (Eglash and Banks, 2014).

Second, a framework based on generative justice must devise ways to avoid the normative "basin of attraction" that can drive well-meaning efforts into extractive value relations. For example, indigenous harvest of brazil nuts, vanilla beans, and other "nontimber forest products" (NTFP) has long been championed by sustainability groups as a means to raise income without ecological destruction. But a recent study comparing NTFP outcomes from 5 groups in the Amazon (Morsello et al., 2012) showed decreases in three crucial measures of well-being--gender equality, income, and cultural activities--when they attempted to move from harvesting to independent processing (such as transformation of nuts into oils) without corporate partnerships.

Questioning why productive relations to technoscience are driven towards this kind of normative "capture" even when attempting alternative forms, TallBear (2015) brings together work in "queer ecology" (e.g. Anglin, 2015) and STS on nonhuman vitalism (Callon, 1986; Pickering, 1995; Bennett, 2010; Barad, 2012) in relation to indigenous knowledge. She cautions that her work "should not be seen as queering indigenous practice. Rather it should be seen as a twenty-first century indigenous knowledge articulation, period" (p. 230). TallBear uses her studies of the Dakota pipestone quarry to show that "the extent to which the blood red stone and indigenous relationships with it have been frozen in time or facilitated in more lively ways" depends on resistance to the forces by which normative conceptions and social forms can "deanimate" the vibrancy of human/nonhuman relations, even when the nonhumans are not biological. 
Finally, the division of unalienated value into different "types" (labor, ecological and expressive) is itself problematic, encouraging dualistic views. If we don't allow for the idea that the various types of value were not separated to begin with, or at least examine their interdependence after Latour's "purification", the potential for generative justice can be damaged by internal contradictions. For example Bauhardt (2014) uses an ecofeminist economics framework to point out missing components in the peer to peer production literature. Without accounting for the gendered division of paid labor, as well as the gendered public/private split, we can lose sight of justice issues around the "care work" for children, the sick and elderly, the household's human ecology, and many other kinds of social provisioning (Safri and Graham, 2011). At the same time, some prominent ecofeminists such as Nobel laureate Wangari Maathai have constricted, rather than expanded, reproductive choice rights (O’Neil, 2009). Stressing the definition of generative justice not only as bottom-up circulation of unalienated value, but also the rights of value generators to create their own conditions of production is a crucial foundation for in reconceptualizing social justice and sustainability.

\section{Acknowledgement}

The author would like to acknowledge NSF grant DGE-0947980 in support of this work. 


\section{References}

Alaimo, S. (2010). Bodily Natures: Science, Environment, and the Material Self. Bloomington: Indiana University Press.

Altieri, M. (2004). "Agroecology versus Ecoagriculture: balancing food production and biodiversity conservation in the midst of social inequity." Commission on Environmental, Economic \& Social Policy CEESP Occasional Papers \#3, pp. 8-28. Retrieved from:

$<$ http://cmsdata.iucn.org/downloads/occasional_paper__altieri.pdf $>$

BARAD, K. (2011). Nature's queer performativity. Qui Parle: Critical Humanities and Social Sciences, 19(2), 121-158.

Bauhardt, C. (2014). "Solutions to the Crisis? The Green New Deal, Degrowth, and the Solidarity Economy: Alternatives to the Capitalist Growth Economy from an Ecofeminist Economics Perspective." Ecological Economics 102, 60-68.

Bellotti, V., Carroll, J. M. \& Han, K. (2013). "Random Acts of Kindness: The Intelligent and Context-Aware Future of Reciprocal Altruism and Community Collaboration." In 2013 International Conference on Collaboration Technologies and Systems (CTS), 1-12.

Boнm, M. (2013, September 6). “The Roots of Russia's Homophobia." Moscow Times. Retreived from:

$<$ http://www.themoscowtimes.com/opinion/article/the-roots-of-russia-shomophobia/485634.html>

Benkler, Y. (2013). "Practical Anarchism: Peer Mutualism, Market Power, and the Fallible State." Politics and Society 4(2), 213-251.

Bennett, J. (2010) Vibrant Matter: A Political Ecology of Things. Durham, NC and London: Duke University Press.

Bennett, J., Strange, N. \& Medrado, A. (2015). “A Moral Economy of Independent Work? Creative Freedom and Public Service in UK Digital Agencies." In James Bennett; Niki Strange. (Eds.). Media Independence: Working with Freedom or Working for Free? (pp. 139-158). London: Routledge.

Blanding, M. \& White, H. (2015, April 6). "How China Is Screwing Over Its Poisoned Factory Workers." Wired. Retrieved from:

$<$ http://www.wired.com/2015/04/inside-chinese-factories/> 
Buechley, L. \& Hill, B. M. (2010). "LilyPad in the Wild: How Hardware's Long Tail is Supporting New Engineering and Design Communities." In Proceedings of Designing Interactive Systems (pp. 199-207). New York, NY: ACM.

Callon, M. (1986). "Some Elements of a Sociology of Translation: Domestication of the Scallops and the Fishermen of St Brieuc Bay." In John Law (Ed.) Power, Action and Belief: A New Sociology of Knowledge (pp. 196-233). London: Routledge \& Kegan Paul.

Campbell, M. N. (2005). Sacred Groves for Forest Conservation in Ghana's Coastal Savannas: Assessing Ecological and Social Dimensions." Singapore Journal of Tropical Geography 26(2), 151-69.

Chopra, S. \& Dexter, S. (2006). "The Political Economy of Open Source Software." International Journal of Technology, Knowledge and Society 1(7), 127-134.

Davies, R.W. (1998). Soviet Economic Development from Lenin to Khrushchev. Cambridge: Cambridge University Press.

Eglash, R. \& Banks, D. A. (2014). "Recursive Depth in Generative Spaces: Democratization in Three Dimensions of Technosocial Self-Organization.” The Information Society 30(2) 106115.

Eglash, R. \& Garvey, C. (2014). "Basins of Attraction for Generative Justice.” In S. Banerjee, Ş. Ş. Erçetin, and A. Tekin (Eds.), Chaos Theory in Politics (pp. 75-88). Springer Netherlands.

Eglash, R. (2016). Generative Technologies from Africa.” In , edited by D. L. Hodgson \& J. A. Byfield (Eds.), Global Africa. University of California Press, 2016. Preprint at:

$<$ https://docs.google.com/document/d/1raRU0CA5CXm4QeEn9MFOWLYYE1btjY27hhdy -BB7rv4/edit>

Ekbia, H. \& NARdi, B. (2014) "Heteromation and Its (dis)contents: The Invisible Division of Labor between Humans and Machines." First Monday 19(6). Retrieved from:

$<$ http://firstmonday.org/ojs/index.php/fm/article/view/5331>

Eltis, W.(1988). "The Contrasting Theories of Industrialization of François Quesnay and Adam Smith." Oxford Economic Papers, 40(2) 269-88.

Magdoff, F. \& Foster, J. B. (2011). What Every Environmentalist Needs to Know about Capitalism: A Citizen's Guide to Capitalism and the Environment. New York, NY: NYU Press.

Engels, F. (1902). The Origin of the Family, Private Property and the State. Chicago: C. H. Kerr. 
FedericI, S. (2012). Revolution at Point Zero: Housework, Reproduction, and Feminist Struggle. Oakland, CA: PM Press.

Feshbach, M. \& Friendly, A. (1993). Ecocide in the USSR: Health and Nature Under Siege. New York, NY: Basic Books.

Fox, S., Ulgado, R. R. \& Rosner, D. (2015). "Hacking Culture, Not Devices: Access and Recognition in Feminist Hackerspaces," CSCW'15, Vancouver, BC; 56-68. ACM Press.

Fuentes-Nieva, R., \& Galasso, N. (2014). Working for the Few: Political capture and economic inequality (Vol. 178). Oxfam.

Graeber, D. (2012). Debt: The First 5,000 Years. New York: Melville House.

Graham, L. (1993). Science in Russia and the Soviet Union. New York, NY: Cambridge University Press.

Gibson-Graham, J. K. (2006). A Postcapitalist Politics. Minneapolis: University of Minnesota Press.

Grinde, D. A. and Johansen, B. E. (1991). Exemplar of Liberty: Native American and the Evolution of Democracy. Los Angeles: American Indian Studies Center, University of California.

Hall, V. (1980). “The Role of Force or Power in Liebig's Physiological Chemistry.” Medical History 24(1), 20-59.

Hamari, J., Mimmi S. \& Ukronen, A. (2015). “The Sharing Economy: Why People Participate in Collaborative Consumption." SSRN Scholarly Paper. Rochester, NY: Social Science Research Network. Retreived from:

$<$ http://papers.ssrn.com/abstract=2271971>

Haraway, D. (1992). “The Promises of Monsters: A Regenerative Politics for Inappropriate/d Others.” In L. Grossberg, C. Nelson, \& P. A. Treichler (eds.), Cultural Studies New York, NY: Routledge.

Haraway, D. (2007). When Species Meet. Minneapolis: U of Minnesota Press.

IRANI, L. (2015). "Hackathons and the making of entrepreneurial citizenship." Science Technology and Human Values, 40(5), 799 - 824.

Kawano, E. M. \& Teller-Ellsberg, J. (Eds.). (2010). Solidarity Economy I: Building Alternatives for People and Planet. Amherst, MA: Center for Popular Economics. 2010. "Building a Solidarity Economy from Real World Practices." Online at: 
$<$ https://www.academia.edu/2472194/Building_a_Solidarity_Economy_from_Real_World_ Practices $>$

KeEn, A. (2007). The Cult of the Amateur: How Today's Internet Is Killing Our Culture. NY: Crown Business.

KIM, S. M. (2015). "The Conditions and Strategies of the Success of Local Currency Movements." Society for Social Work and Research Annual Conference. $<$ https://sswr.confex.com/sswr/2015/webprogram/Paper23495.html>

Kostakis, V. \& Bauwens M. (2014). Network society and future scenarios for a collaborative economy. Basingstoke: Palgrave Macmillan.

Lachney, M., Babbitt B. \& Eglash R. (2016). "Content Aware Software Design in the 'Construction Genre' of Learning Technology.” Software Studies no. 5.

Latour, B. (1993). We Have Never Been Modern. Translated by Catherine Porter. Cambridge, Mass: Harvard University Press.

LANGE, J. (2012). "Division, demand and supply of labour Elements of a theory of population in Adam Smith." XIVème Colloque de 1'Association Charles Gide pour l'étude de la pensée économique, Juin 2012. Retreived from:

$<$ http://www.gredeg.cnrs.fr/colloques/gide/papers/Lange_Division.pdf $>$

Lessig, L. (2009). Remix: Making Art and Commerce Thrive in the Hybrid Economy. New York: Penguin Books.

Matthews, R. C. O., Feinstein, C. H. \& Odling-Smee, J. C. (1982). British Economic Growth, 1856-1973. Oxford: Oxford University Press.

Marx, K. (1989). Karl Marx and Frederick Engels: Collected Works. New York: Intl Pub.

MarX, K. (1976). Capital, vol. I, New York: Vintage.

Marx, K. (1973). Grundrisse: Foundations of the Critique of Political Economy. New York: Vintage Books.

MarX, K. (1974). Political Writings Vol. I: The Revolutions of 1848. New York, NY: Vintage Books/Random House.

Marx, K. (1979). The Letters of Karl Marx. Ed. Saul Kussiel Padover. Englewood Cliffs, NJ: Prentice Hall.

MarX, K. (1842). On Freedom of the Press: Censorship. Rheinische Zeitung, 135, Supplement, May 15. Retrieved from:

$<$ http://www.marxists.org/archive/marx/works/1842/free-press/> 
MAY, K. (2013). “Architecture infused with fractals". Retrieved from: $<$ http://blog.ted.com/architecture-infused-with-fractals-ron-eglash-and-xavier-vilalta/>

McRobbie, A. (2002). "Clubs to Companies: Notes on the Decline of Political Culture in Speeded up Creative Worlds." Cultural Studies 16(4), 516-531.

Miller, E. (2013). "Community economy: Ontology, ethics, and politics for radically democratic economic organizing." Rethinking Marxism: A Journal of Economics, Culture \& Society, 25(4), 518-533.

MIT (2012). "Fighting Peak Phosphorus." Retrieved from:

$<$ http://web.mit.edu/12.000/www/m2016/finalwebsite/solutions/phosphorus.html>

Morsello C., Ruiz-Mallén I., Diaz M. D. M. \& Reyes-García, V. (2012). The Effects of Processing Non-Timber Forest Products and Trade Partnerships on People's Well-Being and Forest Conservation in Amazonian Societies. PLoS ONE 7(8). Retrieved from $<$ http://journals.plos.org/plosone/article?id=10.1371/journal.pone.0043055\#pone-0043055t002>

Olajide, O. J., Makinde, M., Okpako, D. T. \& Awe, S. O. (2000). Studies on the AntiInflammatory and Related Pharmacological Properties of the Aqueous Extract of Bridelia Ferruginea Stem Bark. Journal of Ethnopharmacology, 71(1-2), 153-60.

O’NeIL, P. (2009, January 22). "Pro-life, eco-feminists work for consist ethic of life." National Catholic Reporter. Retrieved from:

$<$ http://ncronline.org/news/pro-life-eco-feminists-work-consist-ethic-life $>$

Ostrom, E. (2010). "Beyond markets and states: polycentric governance of complex economic systems". American Economic Review (American Economic Association) 100 (3): 641-672.

Penn, L. \& Shear, B. (2015). Solidarity economy and community development: emerging cases in three Massachusetts cities, Community Development, 46: 3, 244-260

Pickering, A. (1995). The Mangle of Practice Time, Agency, and Science. Chicago: University of Chicago Press.

Place, Ch. (2015). Impact of complementary currency for sustainability: an integral approach. In: 3rd International Conference on Social and Complementary Currency, 27th, 28th, 29th and 30th of October 2015. Salvador: Federal University of Bahia, 2015. Available from: $<$ http://socialcurrency.sciencesconf.org/conference/socialcurrency/pages/Impact_of_comple mentary_currency_PLACE.pdf> 
Sandoval, M. (2013). "Foxconned Labour as the Dark Side of the Information Age: Working Conditions at Apple's Contract Manufacturers in China." tripleC: Communication, Capitalism \& Critique. Open Access Journal for a Global Sustainable Information Society 11, no. 2 (July 25): 318-47.

Schneider, M. \& McMichael, P. (2010). "Deepening, and Repairing, the Metabolic Rift." The Journal of Peasant Studies 37, no. 3, 461-84.

SchröDinger, E. (1944). What is Life? Cambridge University Press, Cambridge.

Shirky, C. (2011). Cognitive Surplus: Creativity and Generosity in a Connected Age. Penguin Books.

Slay, B. (2009) "Poverty, Inequality, and Social Policy Reform in the Former Soviet Union." United Nations Development Programme. Pp 1-19. Online at:

$<$ http://www.undp.org/content/dam/rbec/docs/Poverty-inequality-and-social-policy-reformin-the-former-Soviet-Union.pdf>

Smith, A. (1776). An inquiry into the nature and causes of the wealth of nations. Glasgow: W.Strahan and T. Cadel.

SteIn, H. (6 April 1994). "Board of Contributors: Remembering Adam Smith". The Wall Street Journal Asia p. A14.

Taubman, W. (2004). Khrushchev: The Man and His Era. Reprint edition. New York: W. W. Norton \& Company.

Wright, E. (2013). “Transforming Capitalism through Real Utopias.” American Sociological Review. 78(1):1-25.

Zeitlyn, D. (2003). "Gift Economies in the Development of Open Source Software: Anthropological Reflections." Research Policy, Open Source Software Development, 32, no. 7 (July): 1287-91. 